\title{
ACCUMULATION OF BORON, ARSENIC AND SELENIUM BY TWO SPECIES OF BIVALVE MOLLUSCS IN EXPERIMENTAL CONDITIONS
}

\author{
Zubcov Elena, Biletchi Lucia, Ciornea Victor \\ Institute of Zoology, Chisinau, Republic of Moldova, elzubcov@mail.ru
}

https://doi.org/10.53937/9789975315975.85

Determination of the tolerance of some species of hydrobiontes to the pollution of habitats and their role in the migration of chemicals in aquatic ecosystems are usually focused on heavy metals, but more recently, some other groups of chemical elements frequently get into the view of experimental hydrobiology and ecotoxicology.

The scope of the work consisted in the determination of the level of accumulation of non-metals B, As, also called metalloids, and Se in Crassiana crassa and Unio tumidus (Bivalvia: Unionidae). The molluscs were collected in July 2016 from the Lower Prut. Under laboratory conditions, 2 groups of specimens of each species were placed in each of 5 aquariums, one being the control. The groups were visibly distinct: the average wet body mass of specimens from C.crassa I group was of $40.1 \mathrm{~g}$, C.crassa II - $22.6 \mathrm{~g}$, U.tumidus I - $39.1 \mathrm{~g}$, and U.tumidus II - of $19.3 \mathrm{~g}$. The volume of water in each aquarium was of $5 \mathrm{I}$, the total mass of molluscs per aquarium averaged $340 \mathrm{~g}$. The used water was collected from the Prut River on the same day and in the same place as molluscs. It contained $93.6 \mu \mathrm{g} / \mathrm{l}$ of $\mathrm{B}, 3.4 \mu \mathrm{g} / \mathrm{l}$ of As and $3.9 \mu \mathrm{g} / \mathrm{l}$ of Se. In order to increase the concentration of $B, A$ s and $S e$ in water of experimental aquariums, solutions with different concentrations of $B-50 / 100 / 150 / 300$ $\mu \mathrm{g} / \mathrm{l}$, As and $\mathrm{Se}-1 / 5 / 10 / 20 \mu \mathrm{g} / \mathrm{l}$ - were used. The chemical analysis was performed by atomic emission spectrometry with inductively coupled plasma.

The correlation coefficient $(r)$ between the concentration of Se in soft tissues of molluscs and in water was of 0.8-0.9 in the case of all 4 groups of molluscs. The same high $r$ values were registered for As in C.crassa I, C.crassa II and U.tumidus I, but for B - only at C.crassa I and U.tumidus I. The accumu- 
lation of chemical elements in molluscs occurs relatively fast. For example, if the ratio between the concentration of $\mathrm{Se}$ in water of aquarium no.5 and that from control one was of 6.1 , than the ratio between the concentration of $\mathrm{Se}$ in soft tissues of specimens from the same aquariums varied from 1.18 (U.tumidus I) to 1.58 (C.crassa II) at the end of 13 days experiment. Thus, the experiment has shown differences in the accumulation of $\mathrm{B}, \mathrm{As}$ and $\mathrm{Se}$ in the soft tissues of molluscs, depending on the nature and concentration of the elements in the aquarium water, the species and age of the molluscs, expressed in the given case by the body mass.

Acknowledgment: The research was done within the project 15.817.02.27A AQUASYS. 
INTERNATIONAL SYMPOSIUM"FUNCTIONAL ECOLOGY OF ANIMALS" 